\title{
Genetic diversity and differentiation in natural Plasmodium falciparum populations inferred by molecular typing of the merozoite surface proteins 1 and 2
}

\author{
Diversidade genética e diferenciação em populações naturais de Plasmodium falciparum \\ inferidas pela tipagem molecular das proteínas de \\ superfície de merozoítos 1 e 2
}

Fabrício J.T. Pereira', José A. Cordeiro², Erika H.E. Hoffmann ${ }^{3}$ and Marcelo U. Ferreira ${ }^{13}$

\begin{abstract}
Genetic diversity and differentiation, inferred by typing the polymorphic genes coding for the merozoite surface proteins 1 (Msp-1) and 2 (Msp-2), were compared for 345 isolates belonging to seven Plasmodium falciparum populations from three continents. Both loci yielded similar estimates of genetic diversity for each population, but rather different patterns of between-population differentiation, suggesting that natural selection on these loci, rather than the transmission dynamics of P. falciparum, determines the variation in allele frequencies among populations.
\end{abstract}

Key-words: Malaria. Plasmodium falciparum. Msp-1. Msp-2. Population genetics.

Resumo Estimativas de diversidade e diferenciação genética, obtidas com a tipagem dos genes polimórficos que codificam as proteínas de superfície de merozoítos 1 (Msp-1) e 2 (Msp-2) foram comparadas em 345 isolados pertencentes a sete populações de Plasmodium falciparum de três continentes. Os dois loci produziram estimativas semelhantes de diversidade genética para cada população, porém com padrões distintos de diferenciação entre populações, sugerindo que a seleção natural nestes loci, em vez da dinâmica de transmissão de P. falciparum, determina a variação de freqüências alélicas entre populações.

Palavras-chaves: Malária. Plasmodium falciparum. Msp-1. Msp-2. Genética de populações.

The genes encoding the polymorphic merozoite surface proteins $1(M s p-1)$ and $2(M s p-2)$ have been extensively used as markers to investigate the genetic diversity and population structure of Plasmodium falciparum ${ }^{3}$. Here we examine how comparable are estimates of genetic diversity and differentiation inferred by $M s p-1$ and Msp-2 typing in the same P. falciparum populations.

Polymorphism at the Msp-1 and Msp-2 loci was examined in 345 isolates belonging to seven $P$. falciparum populations. Five of them were from different sites within the Brazilian Amazon Basin, one from southern Vietnam and one from north-eastern Tanzania (Table 1). Five variable domains or blocks (2, 4a, 4b, 6 and 10) of the Msp-1 gene were typed with PCR using the allele-specific primers described elsewhere ${ }^{11}$. Msp1 alleles were defined as unique combinations of allelic types in variable blocks ${ }^{11}$ Most typing results, except for those for 34 additional isolates from Vietnam, had been previously published ${ }^{7814}$. The central region of Msp-2 (blocks 2 and 3 ) was amplified by PCR and typed by hybridization with allele-specific probes ${ }^{9}$. Msp-2 alleles were defined according to PCR fragment sizes and hybridization patterns. Msp-2 typing results had been

\footnotetext{
1. Laboratório de Parasitologia Molecular. 2. Departamento de Epidemiologia e Saúde Coletiva da Faculdade de Medicina de São José do Rio Preto, São José do Rio Preto,SP. 3. Departamento de Parasitologia do Instituto de Ciências Biomédicas da Universidade de São Paulo, São Paulo, SP.

Financial support: Fundação de Amparo à Pesquisa do Estado de São Paulo (FAPESP), UNDP/World Bank/World Health Organization Special Program for Research and Training in Tropical Diseases and Conselho Nacional de Desenvolvimento Científico e Tecnológico (CNPq). FJTP and EHEH are recipients of studentships from FAPESP, and MUF is a recipient of a research fellowship from CNPq.

Address to: Dr. Marcelo U. Ferreira. Depto. de Parasitologia/ICB/USP. Av. Prof. Lineu Prestes 1374, 05508-900 São Paulo, SP, Brazil.

Tel: 5511 3091-7273, Fax: $55113091-7417$

e-mail: muferrei@usp.br

Recebido para publicação em 10/12/2001.
} 
Table 1 - Geographical origin and estimates of genetic diversity at the Msp-1 and Msp-2 loci for seven Plasmodium falciparum populations

\begin{tabular}{|c|c|c|c|c|c|c|}
\hline \multirow[b]{2}{*}{ Population (origin) } & \multirow[b]{2}{*}{ Years of collection } & \multirow[b]{2}{*}{ No. of isolates typed } & \multicolumn{2}{|c|}{ Msp-1 } & \multicolumn{2}{|c|}{ Msp-2 } \\
\hline & & & No. of alleles & $H^{*}$ & No. of alleles & $H^{*}$ \\
\hline \multicolumn{7}{|l|}{ Brazil } \\
\hline RO1 (Rondônia) & $1985-86$ & 49 & 10 & 0.822 & 12 & 0.889 \\
\hline PA1 (Pará and Amapá) & $1985-86$ & 17 & 6 & 0.785 & 7 & 0.797 \\
\hline PA2 (Pará and Amapá) & $1992-95$ & 17 & 8 & 0.768 & 8 & 0.938 \\
\hline RO2 (Rondônia) & $1995-98$ & 46 & 9 & 0.786 & 16 & 0.896 \\
\hline $\mathrm{AC}($ Acre $)$ & 1999 & 26 & 5 & 0.566 & 9 & 0.818 \\
\hline \multicolumn{7}{|l|}{ Vietnam } \\
\hline VN (Bao Loc) & $1996-97$ & 126 & 19 & 0.884 & 32 & 0.942 \\
\hline \multicolumn{7}{|l|}{ Tanzania } \\
\hline TZ (Tanga) & 1996 & 64 & 13 & 0.855 & 35 & 0.953 \\
\hline
\end{tabular}

*The average gene diversity index $H$ is calculated as $H=[n /(n-1)]\left[1-\Sigma p_{i}^{2}\right]$, where $n$ is the number of isolates sampled and $p_{i}$ is the frequency of each allele at a given locus ${ }^{4}$.

previously published for $\mathrm{RO} 1, \mathrm{RO} 2, \mathrm{VN}$ and $\mathrm{TZ}^{9} ; 60$ additional Brazilian isolates, which constitute the populations PA1, PA2 and AC, were analyzed for the present comparison (Table 1).

Both loci yielded comparable estimates of genetic diversity for each population, as judged by the number of different alleles and the average diversity index $\mathrm{H}^{4}$, defined as the probability of randomly drawing two different alleles from the population sample (Table 1). In other words, both typing systems seemed to be equivalent in terms of their ability to discriminate between unrelated parasite clones or strains within the same population ${ }^{10}$.

Different results were obtained when we used allele frequencies to assess the degree of genetic differentiation among the seven $P$. falciparum populations. Fixation indices $\left(F_{S T}\right)$, which describe the proportion of overall genetic diversity that is attributable to differences between (instead of within) populations ${ }^{13}$, were calculated for pairwise comparisons of allele frequencies for both loci. AC was the population associated with the highest fixation indices for Msp-1 (Table 2), suggesting that gene flow between $A C$ and all other populations is relatively scant. Fixation indices for Msp-1 suggest that more differentiation (less genetic admixture) has occurred between $\mathrm{AC}$ and $\mathrm{RO} 2\left(F_{S T}=0.130\right)$, which were sampled in the 1990s in two neighboring regions of Brazil (distance between collection sites of about $600 \mathrm{~km}$ ), than between parasites on different continents $\left(F_{S T}\right.$ values between 0.010 and 0.119 in pairwise comparisons). The overall $F_{s T}$ estimate for $M s p-1$ was 0.095 . In contrast, less genetic differentiation between populations was usually detected by $M s p-2$ typing (Table 2), with an overall $F_{S T}$ estimate of 0.072 . No association between $F_{S T}$ values and

Table 2 - Matrix of pair-wise $F_{S T}$ values ${ }^{*}$ for Msp-1 (above diagonal) and Msp-2 (below diagonal) in comparisons of seven Plasmodium falciparum populations.

\begin{tabular}{lrrrrrrr}
\hline & RO1 & PA1 & PA2 & RO2 & AC & VN \\
\hline RO1 & - & 0.013 & 0.052 & 0.015 & 0.088 & 0.060 \\
PA1 & 0.069 & - & 0.038 & 0.016 & 0.093 & 0.079 \\
PA2 & 0.025 & 0.046 & - & 0.035 & 0.193 & 0.064 & 0.055 \\
RO2 & 0.024 & 0.069 & 0.029 & - & 0.130 & 0.055 & 0.039 \\
AC & 0.068 & 0.073 & 0.046 & 0.062 & 0.010 \\
VN & 0.028 & 0.033 & 0.014 & 0.031 & 0.041 & 0.092 \\
TZ & 0.024 & 0.041 & 0.016 & 0.027 & 0.042 & 0.031 \\
\hline
\end{tabular}

${ }^{*}$ The fixation index $\left(F_{\mathrm{ST}}\right)$, ranging between 0 and 1, estimates the proportion of the overall variation in allele frequencies that is due to variation between (instead of within) populations; high $F_{\mathrm{ST}}$ values indicate high levels of genetic differentiation (i. e., low levels of gene flow and genetic admixture) between pairs of populations ${ }^{4}$.

geographical distance was apparent for either locus. These findings suggest that natural selection on these loci, rather than the transmission dynamics of $P$. falciparum, determines the observed patterns of between-population variation in allele frequencies. Thus, they argue against the use of non-neutral polymorphic markers (i. e., markers potentially under selection pressure, such as those encoding antigens) in studies of population genetics of malaria parasites.
An alternative way of looking at these data was based on analysis of dependence (ANADEP) ${ }^{6}$. ANADEP is a geometrical method of analysis. Allele frequencies of each population are represented as a point in the real space whose dimension is the total number of alleles detectable by the typing procedure ${ }^{12}$. ANADEP may be thus regarded as an equivalent to principal component analysis, a method of multivariate analysis that is extensively used in Biology and Epidemiology. In contrast with principal 
component analysis, however, ANADEP is suitable for use with categorical variables. The first two factors of dependence, which together explain nearly two-thirds of the overall dependence among populations, were considered to describe the dispersion of populations, according to allele frequencies, in a two-dimensional space (Figure 1). Msp-1 (but not Msp-2) allele frequencies clearly differentiated $\mathrm{AC}, \mathrm{VN}$ and $\mathrm{PA} 2$ from all other populations. Conversely, RO1 and RO2 were well differentiated from all other populations by considering Msp-2 (but not Msp-1) allele frequencies (Figure 1). A quite similar overall pattern emerged when the three first factors of ANADEP, which together explain between $74 \%$ and $77 \%$ of the overall dependence, where taken into account (data not shown). The overall ability to detect genetic differentiation among populations, as shown by their dispersion in Figure 1, was considerably higher for Msp-1 than for Msp-2.
Describing the patterns of genetic differentiation among parasite populations is of considerable interest for population geneticists ${ }^{15}$. Here we illustrate some limitations that are inherent to studies of genetic relationships of malaria parasite populations based on non-neutral markers, such as the widely used Msp-1 and Msp-2 antigenic loci. In short, these markers may differ in their ability to discriminate between populations, even when they are equivalent in their ability to discriminate between clones and strains within the same population, especially when natural selection is a major source of variation in allele frequencies. Putatively neutral markers (i. e., polymorphisms located in noncoding DNA sequences, that are not under selection), such as most hypervariable microsatellite loci, however, provide geneticists with excellent tools to overcome these limitations ${ }^{2}$.

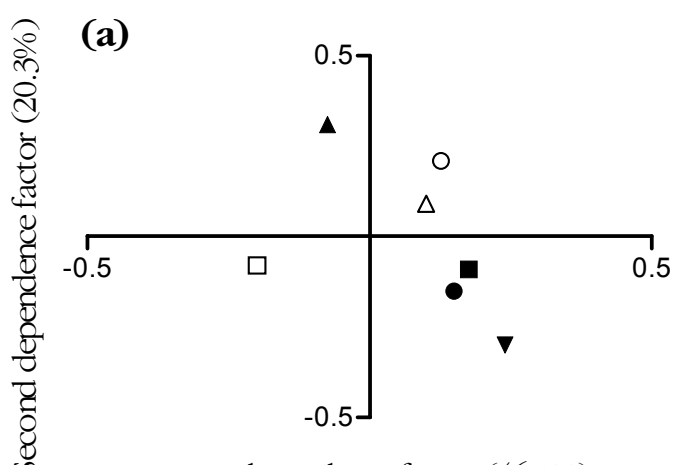

First dependence factor $(46.1 \%)$

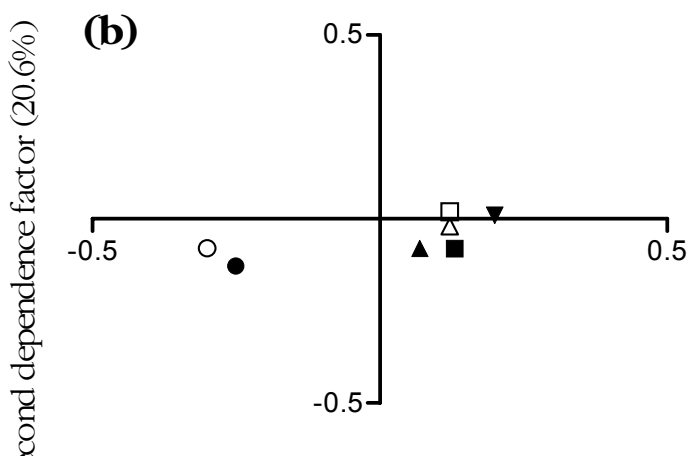

First dependence factor (41\%)

Figure 1 - Patterns of differentiation of seven Plasmodium falciparum populations, as estimated by analysis of dependence of allele frequencies of Msp-1 (a) and Msp-2 (b). The first two dependence factors, which together explain about two thirds of the overall dependence, are considered in this analysis; the percentage of overall dependence explained by each factor is given in parentheses. Symbols for populations are as follows: RO1 O:PA1 -PA2 :RO2 : AC V:VN $\square$ and TZ $\triangle$. Populations are described in Table 1. 


\section{REFERENCES}

1. Anderson TJC, Haubold B, Williams JT, Estrada-Franco JG, Richardson L, Mollinedo R, Mockarie M, Mokili J, Mharakurwa S, French N, Whitworth J, Velez ID, Brockman AH, Nosten F, Ferreira MU, Day KP. Microsatellites reveal a spectrum of population structures in the malaria parasite Plasmodium falciparum. Molecular Biology and Evolution 17: 1467-1482, 2000.

2. Awadalla P, Walliker D, Babiker H, Mackinnon M. The question of Plasmodium falciparum population structure. Trends in Parasitology 17:351-353, 2001.

3. Babiker $\mathrm{H}$, Walliker D. Current views on the population structure of Plasmodium falciparum: implications for control. Parasitology Today 13: 262-267, 1997.

4. Conway DJ. Population genetics. In: Thompson RCA (ed) Molecular Epidemiology of Infectious Diseases, Arnold, London, p. 45-58, 2000.

5. Conway DJ, Cavanagh DR, Tanabe K, Roper C, Mikes ZS, Sakihama N, Bojang KA, Oduola AMJ, Kremsner PG, Arnot DE, Greenwood BM, Mcbride JS. A principal target of human immunity to malaria identified by molecular population genetic and immunological analyses. Nature Medicine 6: 689-692, 2000.

6. Cordeiro JA. Analysis of Dependence. Technical Report, Instituto de Matemática da Universidade Estadual de Campinas, Campinas, 1987.

7. Ferreira MU, Liu Q, Kimura M, Ndawi BT, Tanabe K, Kawamoto $F$. Allelic diversity in the merozoite surface protein-1 and epidemiology of multiple-clone infections in northern Tanzania. Journal of Parasitology 84: 1286-1289, 1998.
8. Ferreira MU, Liu Q, Zhou M, Kimura M, Kaneko O, Thien HV, Isomura S, Tanabe K, Kawamoto F. Stable patterns of allelic diversity at the merozoite surface protein-1 locus of Plasmodium falciparum in clinical isolates from southern Vietnam. Journal of Eukaryotic Microbiology 45: 131-136, 1998.

9. Hoffmann EHE, Silveira LA, Tonhosolo R, Pereira FJT, Ribeiro WL, Tonon AP, Kawamoto F, Ferreira MU. Geographical patterns of allelic diversity in the Plasmodium falciparum malaria-vaccine candidate, merozoite surface protein-2. Annals of Tropical Medicine and Parasitology 95: 117-132, 2001.

10. Hunter PR, Gaston MA. Numerical index of the discriminatory ability of typing systems: an application of Simpson's index of diversity. Journal of Clinical Microbiology 26: 2465-2466, 1988.

11. Kaneko O, Kimura M, Kawamoto F, Ferreira MU, Tanabe K. Plasmodium falciparum: variation in the merozoite surface protein 1 gene in wild isolates from southern Vietnam. Experimental Parasitology 86: 45-57, 1997.

12. Lapenta AS, Bicudo HEMC, Ceron CE, Cordeiro JA. Esterase patterns and phylogenetic relationships of species and strains included in the Drosophila buzzati cluster. Cytobios 96: 95-107, 1998.

13. Nei M, Chesser RK. Estimation of fixation indices and gene diversities. Annals of Human Genetics 47: 253-259, 1983.

14. Silva NS, Silveira LA, Machado RLD, Póvoa MM, Ferreira MU. Temporal and spatial distribution of variants of merozoite surface protein-1 (MSP-1) in Plasmodium falciparum populations in Brazil. Annals of Tropical Medicine and Parasitology 94: 675-688, 2000. 